EPiC Series in Language and Linguistics
Volume 3, 2018, Pages 91-96
LSP in Multi-disciplinary contexts of
Teaching and Research. Papers from the
16th International AELFE Conference

\title{
English for History: Designing a bilingual glossary of specific terms
}

\author{
Eugen Radu Wohl \\ Faculty of Letters, Babeș-Bolyai University \\ 400124 Cluj-Napoca (Cluj)
}

\begin{abstract}
The purpose of the paper is to present a report on the motivations, objectives, initial research stages and preliminary results of a research project, conducted during the 2016-2017 academic year at the Faculty of Letters, Babeș-Bolyai University of Cluj-Napoca, Romania, focused on designing a bilingual (Romanian-English) glossary of historical terms. The desire of the research team, myself as a team leader and my associates, two PhD students in History, Faculty of History and Philosophy, BBU Cluj-Napoca, is for this glossary to be published at the beginning of the 2017-2018 academic year and, consequently, for it to become a useful tool for all the specialists in the field of History (with all its encompassing subfields: Archaeology, Archival Studies, Art History, Historiography, Library Studies and so on) willing to publish research papers in English, translate or access English bibliographical titles pertinent to their fields of study.

The paper will attempt both a brief presentation of the current status of "English for History" within the general frame of English for Specific Purposes (ESP), in order to better understand the context for our research in progress, as well as an overview of the research steps and of the most important results up to this point.
\end{abstract}

Keywords: ESP/ Lexicography/ Specific Terminology

\section{Main text}

\section{Introduction}

The aim of the present paper is to outline the research stages that, by the end of the 2016-2017 academic year (September 2017), will lead to the publishing of a bilingual, Romanian-English, glossary of historical terms, with a focus on the motivations behind this research project, its objectives, and its preliminary phases (already completed). The overall purpose of the research team myself, as project manager, and Marian Horvat and Alexandru Piticari, PhD students in History at the Faculty of History and Philosophy, BBU Cluj, Romania - is to design a book that will conceivably become an indispensible tool for researchers in the field of History (and all adjacent subfields), as 
well as for linguists, translators and ESP instructors, when confronted with the terminological particularities of "English for History". As such, it is an interdisciplinary undertaking, covering aspects from the fields of Linguistics, Lexicography, English Language Teaching (ELT), English for Specific Purposes (ESP), History and Historiography.

\section{Motivations and objectives of the research}

The motivations behind this research project were threefold: the lack of specialized resources in the "English for History" branch of study, the increasing role of English as an academic lingua franca and, consequently, the lack of appropriate resources for both translators and History specialists in Romania when confronted with reading and translating specialized resources or with writing and publishing their research findings in international academic journals.

First of all, as we observed in a research conducted in 2016, the subfield of "English for History" is insufficiently developed, "in the majority of cases the syllabi and course materials [of university "English for History" courses] have not been transformed into published textbooks" (Wohl, 2016, p. 150), with only a handful of specialized textbooks published worldwide. The number of specialized dictionaries for the field of History published in English, while significantly larger, consists mainly of works designed primarily for native speakers or for proficient users of the language. The explanation for this is to be found in the fact that "English for History" is generally included in the wider area of “academic Englishes" (Johns \& Dudley-Evans, 1991, p. 298), a subdivision English for Academic Purposes (EAP), or, according to Hutchinson and Waters (1991), in the fact that it belongs to the English for Social Sciences (ESS) category, a less common branch of ESP, "probably because it is not thought to differ significantly from more traditional humanities-based General English" (pp. 16, 18).

Unlike the category "English for work/training (EOP/EVP/VESL: English for Occupational Purposes/English for Vocational Purposes/Vocational English as a Second Language)" (Hutchinson \& Waters, 1991, p. 16), which is more commercially-oriented ("English for Tourism" or "English for Business", for instance), the English for Social Sciences category in which "English for History" is included, is more or less restricted to academic settings.

The second reason behind this project stemmed from acknowledging "the rise of English as the hegemonic language of scientific communication" and that "English writing for publication in internationally-indexed journals has generally been accepted as the norm in science and technology" (Meng, 2015, p. 44). This is even truer in the context of the European Union and the ever-expanding political, cultural, social and economic relations between its member states, as well as the EU's liaisons with other European countries:

For 21st-century Europeans, English serves a wider range of purposes well beyond face-toface contact - through mass communication and media, including print, audio-visual, and electronic media - than ever before in its history. Its functional range and societal depth are the result of expanding opportunities for contact with and use of English among Europeans within Europe as well as with English speakers outside Europe (Berns, 2009, p.195).

In a 2004 study conducted on 31 scholars from Slovakia, Hungary and Spain, three "nonAnglophone-center contexts" where the "instrumental use" of English "is increasing" (p. 667), Curry and Lillis also observed that "scholars who are working outside of English-dominant contexts seem to be under increasing pressure to publish in the medium of English" (p. 680), concluding that TESOLEAP professionals "should ideally work alongside discipline specialists who are actively publishing in their specific academic fields" and "support efforts for professionals across multiple sites to work collaboratively toward the broader goal of academic knowledge production" (pp. 682-683). Acknowledging that close collaboration between professionals from different fields is not always possible, TESOL-EAP experts can instead create adequate instruments, specialized dictionaries or 
glossaries, able to facilitate the EAP-related activities of specialists from various fields.

In this context, the third reason is a direct consequence of the previous one and it refers to the lack of any specialized linguistic tools capable to assist Romanian experts from the field of History to conduct their academic research in an international context. The majority of bilingual EnglishRomanian and Romanian-English dictionaries focus exclusively on general English, insufficiently covering specific terminology, and the specific dictionaries and encyclopaedias available are exclusively monolingual, written either in Romanian or in English. Such works, unquestionably useful for research, were designed only with the users' field-related needs in mind, not focusing on their linguistic needs and, as such, they prove difficult to use in professional English writing, reading or translating enterprises.

\section{Designing the Glossary: A Focus on the Pre-lexicography}

In the above-mentioned context, the publishing of a linguistic instrument especially designed for the field of History appeared as imperative and our research was divided into the following steps:

- Planning the research and identifying the target beneficiaries of the proposed bilingual work

- Determining the lexicographic style of the work and classification method of the lexicographic information presented

- Establishing the "headword list" (Attkins \&Rundell, 2008, p. 178) or the "lemma selection" (Bergenhotz \& Tarp, 1995, p. 98)

- Translating the database (Attkins \&Rundell, 2008, p. 465) or the "equivalent selection" (Bergenhotz \& Tarp, 1995, p. 104)

- Revising the "bilingual entries" (Attkins \&Rundell, 2008, p. 484) and preparing the manuscript for publication

This section however, will only focus on the first two research phases, what Attkins and Rundell call "pre-lexicography" (p. 15), concerned with identifying the potential users of such work and, consequently, establishing the lexicographic style that would best serve to highlight the lexicographic information, both "dictionary information" and "vocabulary information" (Hartman \& James, 2002, p. 85), especially compiled for our target users. As stated by H. Jackson (2013), these germinal stages are fundamental because:

It is during this phase that crucial decisions about the database structure and its inventory must be made, based on an analysis of the intended users and their needs. These decisions condition how the data in a later phase can be presented to the end-user and how it can be re-used in other applications. (p. 36)

In this respect, at this initial theoretical stage, such works as Manual of Specialized Lexicography, edited by H. Bergenholtz and S. Tarp (1995), R. R. K. Hartmann and Gregory James' Dictionary of Lexicography (2002), B. T. Sue Atkins and M. Rundell's The Oxford Guide to Practical Lexicography (2008), or The Bloomsbury Companion to Lexicography, edited by Howard Jackson (2013), were among the works that proved instrumental in both clarifying the investigative process and better conceptualizing the research endeavour.

Applying Bergenholtz and Tarp's distinction between "experts", "semi-experts" and "laypeople" in determining "whether the corpus should be composed of texts which are the result of subject-fieldinternal or -external communication" (Bergenholtz \& Tarp, 1995, p. 19) to the field of History, as well as based on a quantitative and qualitative investigation of a series of representative monolingual specialized dictionaries in English (9 titles) and Romanian (5 titles), this early research stage emphasized the need for a bilingual, Romanian-English, dictionary-type work, designed by "experts" 
in the fields of Linguistics and History and intended for "experts" in the field of History, "semiexperts", such as the students in History, and "laypeople", professional translators and prospective ESP instructors. By analysing the results of English language diagnostic tests administered to students of the Faculty of History and Philosophy, BBU, Cluj-Napoca, Romania - 222 students tested in 2015 and 258 tested in 2016 (see Table.1 below) -, as well as by consulting bibliographical resources published in English by history specialists from Romania (scientific articles and specialized books), the research team concluded that the core users of this work (its lexicographic style still unclear) would most probably be Romanian professionals and students in the field of History with an Intermediate, Upper-intermediate or Advanced level of English (B1-B2-C1, according to CEFR), confronted with two EAP-related situations: on the one hand, the urgency to write and publish their research findings in English and, in close relation, the need to consult relevant resources published in English. On the other hand, a secondary category of users would be represented by the professional translators and "English for History and Archaeology" teachers, a numerically smaller category, proficient in English (C2 Level), willing to familiarize themselves with History-related terminology in English.

Table 1. English language level of students in History, BBU, Cluj-Napoca.

\begin{tabular}{ccccccc}
\hline $\begin{array}{c}\text { Academic } \\
\text { year }\end{array}$ & Level A1 & Level A2 & Level B1 & Level B2 & Level C1 & Level C2 \\
\hline $2015-2016$ & 7 & 15 & 62 & 128 & 10 & 0 \\
$2016-2017$ & 11 & 22 & 56 & 94 & 71 & 4 \\
\hline
\end{tabular}

To be able to meet the linguistic needs of the main users, experts and semi-experts, we came to realize that compiling an all-encompassing reference work, a Romanian or World History bilingual dictionary containing both linguistic and encyclopaedic entries (such as important names and dates), would prove counterproductive and would only partially address the language problems of our users. As a result, distinguishing between a dictionary, "used for an increasingly wider range of alphabetic (but also thematic), general (but also specialised), monolingual (but also bilingual and multilingual) reference works, from the polyglot to the historical and the pedagogical dictionary" (Hartmann \& James, 1998, p. 41) and a glossary, "a type of REFERENCE WORK which lists a selection of words or phrases, or the terms in a specialised field, usually in alphabetical order, together with minimal definitions or translation equivalents (Hartmann \& James, 1998, p. 63)", and, at the same time, based on the distinction between "production-oriented" and "reception-oriented" dictionaries operated by M. Hannay (2003), "with immediate consequences for the content and organisation of a dictionary" (p. 146), the research team settled on designing a bilingual, Romanian to English, glossary of historical terms, understood as a language-focused reference work, meant to assist the user in both language production, discovering "the expression she needs in another language than her own for expressing a given idea in a given context, and may well at the same time wish to establish how she should use the expression in question" (Hannay, 2003, p. 145), and language reception, when attempting "to understand something about a given lexical item in another language than her own, for instance in order to better understand a text or in order to translate the expression into her own language" (Hannay, 2003, p. 146).

In order to accomplish these tasks, we believe that a glossary that provides key concepts from the field of History, presented in field-specific contexts through bilingual selections of specialized texts (primary and secondary sources), is able to emphasize how a specific term is used in the two languages and assist the user in his production process. As such, all the lemma included in the glossary (nouns, verbs, adjectives, collocations) will be organized as follows (an organization that, we hope, can also emphasize the standard lemmatisation criteria employed): 
Table 2. Glossary entry designed by Eugen Wohl.

a accede (la tron), $v b$. intranz. - to accede to (the throne) /Br. E.: æk'si:d / phr v.

„În acest an moare hanul Uzbeg şi tot acum accede la tron regele Ludovic al Ungariei." (Laurențiu Rădvan, Orașele din Țările Române în Evul Mediu, Iași, Editura Universității „Alexandru Ioan Cuza”, 2008, p. 328)

"Though James pretended to support in public the dignity of the nation against France, he is said to have very early entered privately into her pay. The emptiness of the exchequer $(\rightarrow$ VISTERIE) when he acceded to the throne, in spite of his management and economy, threw him into difficulties and distress. (James MacPherson, The History of Great Britain from the Restoration to the Accession of the House of Hannover, vol.1, 1775, pp. 430-431).

$\rightarrow$ SCAUN DE DOMNIE; TRON

Table 3. Glossary entry designed by Marian Horvat.

breaslă -e, s.f. - guild-s / Br. E.: gıld / n. C.

"După cum este bine cunoscut, breasla îndeplineşte numeroase funcţii specifice (de ordin economic), dar şi militare, politice şi religioase.” (Lidia Gross, Bresle şi confrerii sau despre pietatea urbană în Transilvania medievală (sec. XIV-XVI), Cluj-Napoca, Editura Argonaut, 2014, p. 118-119)

"Guilds were to be found in the countryside as well as in the towns, and most were able to combine a religious purpose along with their secular pursuits of supervising conditions of manufacture and trade ( $\rightarrow$ COMERT $)$. But the chief urban guilds were primarily economic. They were associations of producers." (Norman Pounds, The Medieval City, Greenwood Press, 2005, p. 112)

Table 4. Glossary entry designed by Alexandru Piticari

scaun de domnie, sintagmă - (royal) throne -s / Br. E.: $\theta$ rown / collocation. C.; $n$. C.

„Așa cum se va vedea și în alte împrejurări, Constantin Mavrocordat a asociat în politica sa

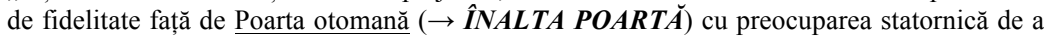
asigura modernizarea Moldovei și a Țării Românești, în ale cărora scaune de domnie s-a urcat." (Florin Constantiniu, Constantin Mavrocordat Reformatorul, București, Editura Enciclopedica, 2015, p.57)

"May it please you Majesty, We your Majesty's most dutiful and loyal Subjects, humbly beg Leave to approach your Royal Throne, to condole with your Majesty upon the Death of our late gracious Sovereign, your Royal Father, and with Hearts full of Loyalty and Affection to congratulate you on your peaceable and happy Accession to the Throne." (The Addresses to King George II on His Accession to the Throne, 1727, p. 46)

\section{$\rightarrow$ A ACCEDE (LA TRON); TRON}


In order to address the aspect of the reception, the glossary will also include, at the end, an English-Romanian dictionary list, in its simplest form, providing users with easy access to the English to Romanian translation of the specialized terms, arranged alphabetically, and to the page number where the entry is to be found:

Table 5. English-Romanian dictionary list (sample).

\begin{tabular}{ll}
\hline Dictionary & Page number \\
\hline accede to (the throne)- a accede (la tron) & 10 \\
guild - breaslă & 24
\end{tabular}

The third and fourth step of this ongoing ESP lexicography research project - lemma selection, undertaken for the most part by Marian Horvat and Alexandru Piticari, translating the headword corpus, providing equivalents into English, as well as identifying the excerpts (primary and secondary sources, edited and unedited text) to best illustrate the use of the historical terms in context - have managed thus far to lead to the completion of approximately 1000 specialized entry words.

Taking everything into account, it is our belief that, once the research is completed and the Bilingual Glossary published (Autumn 2017), it will manage to become a reference work for all researchers in the field of History, when faced with writing, consulting, translating scientific articles or books in English, for qualified translators, as well as for ESP instructors devising language courses for students in History.

\section{Acknowledgements}

Research project financed by the "Young Researchers Fellowship Grants", Babeș-Bolyai University, Cluj-Napoca, Romania, contract no. 3182/23.03.2016.

\section{References}

Atkins, B.T. \& Rundell, M. (2008). The Oxford Guide to Practical Lexicography. Oxford: Oxford University Press, 2008. Bergenholtz H.\& Tarp S. (1995), Manual of Specialized Lexicography. Amsterdam/Philadelphia: John Benjamins Publishing Company.

Berns, M. English as lingua franca and English in Europe (2009). World Englishes, Vol. 28, No. 2, pp. 192-199.

Curry, M. J. \& Lillis T. Multilingual Scholars and the Imperative to Publish in English: Negotiating Interests, Demands, and Rewards (2004). TESOL QUARTERLY, vol. 38, no. 4, Winter, 663-688.

Hannay, M.(2003). Types of Bilingual Dictionaries. In Sterkenburg, Piet van (ed.), A Practical Guide to Lexicography

(pp. 145-153), volume 6, Amsterdam: John Benjamins Publishing Company.

Hartmann, R.R.K. \& James, G. (2002). Dictionary of Lexicography. London and New York: Routledge.

Hutchinson, T. \& Waters, A. (1991). English for Specific Purposes. A learning-centred approach. Cambridge: Cambridge University Press.

Jackson, H. (ed.). (2013). The Bloomsbury Companion to Lexicography. London and New York: Bloomsbury Academic.

Johns, Ann M. \& Dudley-Evans, Tony. (1991). English for Specific Purposes: International in Scope, Specific in Purposes. TESOL Quarterly. vol. 25, no.2, Summer, 297-314.

Meng, G., English Writing for International Publication in the Age of Globalization: Practices and Perceptions of Mainland Chinese Academics in the Humanities and Social Sciences (2015). Publications, 3, 43-64.

Wohl, E.(2016). English for History: An Analysis of University Textbooks in Romania. In Teglaș C., Mihele R. \& Mezei V. (eds.), Dinamica limbajelor de specialitate. Tehnici și strategii inovatoare (pp. 149-167), Cluj-Napoca: Casa Cărții de Știință. 